\title{
EDUCATION, SOCIAL EQUALITY AND ECONOMIC GROWTH: A VIEW OF THE LANDSCAPE
}

\author{
THORVALDUR GYLFASON \\ GYLFI ZOEGA
}

\author{
CESIFO WORKING PAPER NO. 876 \\ CAtegory 5: Fiscal Policy, Macroeconomics and Growth \\ FEBRUARY 2003
}

\author{
Presented at CESifo CONFERENCE ON Globalization, \\ INEQUALITY AND WELL-BEING, NOVEMBER 2002
}

\footnotetext{
An electronic version of the paper may be downloaded

- from the SSRN website: www.SSRN.com

- from the CESifo website: www.CESifo.de
} 


\title{
EDUCATION, SOCIAL EQUALITY AND ECONOMIC GROWTH: A VIEW OF THE LANDSCAPE
}

\begin{abstract}
Education has been one of the key determinants of economic growth around the world since 1965. In this paper, we discuss three different measures of education, and consider their relationship to the distribution of income as measured by the Gini coefficient as well as to economic growth across countries. The three measures are: (a) gross secondary-school enrolment, (b) public expenditure on education relative to national income and (c) expected years of schooling for girls. We show that all three measures of education are directly related to income equality across countries. In a sample of 87 countries at all income levels, we also find that more and better education appears to encourage economic growth directly as well as indirectly through increased social equality and cohesion. Our regression results survive the introduction of regional dummy variables for Africa, Asia and Central and South America. We argue that the empirical relationship between education, on the one hand, and growth and equality, on the other hand, can help account for the positive correlation between the two latter variables that has been documented in the literature.
\end{abstract}

JEL I28, O15, O40.

Thorvaldur Gylfason

Faculty of Economics and Business

Administration

University of Iceland

101 Reykjavik

Iceland

gylfason@hi.is

\author{
Gylfi Zoega \\ Department of Economics \\ Birkbeck College - University of London \\ 7-15 Gresse Street \\ London W1P 2LL \\ United Kingdom \\ gzoega@econ.bbk.ac.uk
}

We are indebted to our discussant, Eytan Sheshinski, and other participants in the CESifo conference on Globalization, Inequality and Well-Being in Munich 8-9 November 2002 for helpful comments. Financial support from Jan Wallanders och Tom Hedelius Stiftelse in Sweden is also gratefully acknowledged. 


\section{Introduction}

It is a widely held view among economists that economic efficiency and social equality are incompatible if not outright mutually exclusive. The perceived but poorly documented trade-off between efficiency and equality is sometimes regarded as one of the main tenets of modern welfare economics. One of the key ideas behind this perception is that increased inequality enhances private as well as social returns to education and to exerting effort in the hope of attaining a higher standard of living. Redistributive policies may then thwart these tendencies and blunt incentives by penalizing the affluent through taxation and rewarding the poor. Economic efficiency - both static and dynamic - suffers in the process, or so the argument goes.

The revival of economic growth theory in recent years has brought dynamic efficiency to the fore. The empirical testing of the theory has involved estimating reduced-form equations in cross sections (sometimes also panels) of countries where the dependent variable is the average rate of growth of output per capita over a long period and the right-hand side of the equation has initial output per capita - to capture a catch-up effect, or convergence - and a set of other possible explanatory variables among the regressors. More often than not, measures of income equality have turned out to have a positive effect on economic growth across countries. Thus Alesina and Rodrik (1994), Persson and Tabellini (1994) and Perotti (1996) report that equality is good for growth. ${ }^{1}$ These empirical results - showing, by and large, that rapid growth tends to go together with more, not less, equality - have helped to inspire a number of authors to attempt an explanation.

Numerous models have been developed to explain the apparent absence of a tradeoff between efficiency and equality. First, large inequalities of income and wealth may trigger political demands for transfers and redistributive taxation. To the extent that transfers and taxation distort incentives to work, save and invest, inequality may impede growth. A classic example of the effects of such a system of taxes and transfers is regional transfers in Italy. High taxes in northern Italy are used to subsidize ailing enterprises and public employment in the south, the Mezzogiorno.

\footnotetext{
${ }^{1}$ Barro (2000) uses a panel of countries over the period from 1965 to 1995 to estimate the relationship between economic growth and equality and finds - by studying the interaction of the Gini coefficient and the initial level of income in a growth regression - that increased equality tends to increase growth in poor countries and retard growth in richer countries, but he finds no support for a relationship between equality and growth in his sample as a whole.
} 
These subsidies have been shown to distort incentives and create inefficiencies in both parts of the country. At a theoretical level, an increase in the rate of redistributive taxation on capital tends to reduce the return to saving and hence lower the long-run rate of growth of output per capita. ${ }^{2}$ Moreover, the initial extent of inequality probably makes a difference. An equalization of incomes and wealth in countries with gross inequities, such as Brazil where the Gini coefficient is 60 , would seem likely to foster social cohesion and peace and thus to strengthen incentives rather than weaken them, whereas in places like Denmark and Sweden, where the Gini coefficient is 25 and incomes and wealth are thus already quite equitably distributed by world standards, further equalization might well have the opposite effect. Excessive inequality may be socially divisive and hence inefficient: it may motivate the poor to engage in illegal activities and riots, or at least to divert resources from productive uses, both the resources of the poor and those of the state. Social conflict over the distribution of income, land or other assets can take place through labour unrest, for instance, or rent seeking which can hinder investment and growth (see Benhabib and Rustichini, 1996). Also, national saving may be affected by inequality if the marginal propensity to save depends on the level of income, i.e., if the rich have a higher propensity to save than the poor (see Kaldor, 1956). In this case inequality may be good for growth in that the greater the level of inequality, the higher is the saving rate and hence also the rate of investment and economic growth. ${ }^{3}$ Unfortunately for this line of thought, Barro (2000) finds no empirical evidence of a link between inequality and investment, but we do.

At last, it is easy to think of ways in which increased equality may help strengthen education rather than hurting it as suggested by the political-economy literature reviewed in brief at the beginning of this discussion. If so, increased equality may thereby also encourage economic growth through education. Galor and Zeira (1993), Aghion (1998) and Aghion, Caroli and García-Peñalosa (1999) argue that this outcome is likely in the presence of imperfect capital markets. To see this, imagine that each member of society has a fixed number of investment opportunities,

\footnotetext{
${ }^{2}$ It is not clear, however, that this type of political-cum-fiscal explanation necessarily implies an inverse relationship between inequality and growth, for it is possible that during the redistribution phase increased equality and a drop in growth go hand in hand, especially in panel data that reflect developments over time country by country as well as cross-sectional patterns. However, Perotti (1996) finds little empirical support for this type of explanation.

${ }^{3}$ Against this Todaro (1997) suggests that the rich may invest in an unproductive manner - think
} 
imperfect access to credit and different endowments of inherited wealth. In such a world the rich would end up using up many of their investment opportunities while the poor could only use a few. Therefore, the marginal return from the last investment opportunity of the rich would be much lower than the marginal return of the last investment opportunity of the poor. Redistribution of wealth from the rich to the poor would increase output because the poor would then invest in more productive projects at the margin. This argument can also be applied to investment in human capital if we assume diminishing returns to education. In this case, taking away the last few quarters of the university education of the elite and adding time to the more elementary education of the poor would raise output and perhaps also long-run growth, other things being equal. Income redistribution would reverse the decline in investment in human capital resulting from the credit-market failure.

The main aim of this paper is to explore empirically the possible relationships and interactions among equality, education and economic growth in a sample of 87 industrial and developing countries in the period from 1965 to 1998. The empirical relationship between the initial level of human capital and economic growth is well established and appears to be more robust than the relationship between measures of equality and growth. The paper proceeds as follows. In Section 2, we consider further explanations for the apparent relationship between equality and growth in the data. In Section 3, we present cross-country correlations between three different measures of education, equality and economic growth, and thus allow the data to speak for themselves. In Section 4, we attempt to dig a little deeper and report the results of multiple regression analysis where growth is traced to education and equality as well as a number of other factors commonly used in growth regression analysis, and where some of the determinants of growth, including education and equality, hang together. Section 5 concludes.

\section{Income distribution, education and growth}

We have described several possible explanations for the positive association between equality and growth found in the data. In an accompanying paper (Gylfason and Zoega, 2003b), we propose a model that embeds some of the mechanisms described in the previous section in an overlapping-generations context. We will discuss this model

of yachts and expensive cars. 
briefly here.

Imagine a world where, not unrealistically, parents support their children who then spend their parental allowance on consumption and education and save the rest in the form of physical capital (think of stocks!). They then enter the labour market, endowed with their human capital, or education, as well as their initial savings plus any inheritance left over by their (by now deceased) parents. During their working life their savings are augmented when wage income is only partly spent on consumption, or given to the next generation, the rest being added to savings, hence the capital stock. When this generation finally passes away their capital it is left over to the young. The world continues forever but each individual has a finite lifespan.

This framework presents a familiar picture of parents supporting their children and then leaving the remainder of their wealth to the young generation. The young acquire both human capital - through education - and physical capital - mostly from inheritance - and then make a living as adults, consume, and support the next generation and finally leave their remaining wealth to that generation.

In such a setting endogenous growth can arise because of complementarities between human and physical capital. Diminishing returns to either factor of production never set in because both factors grow together - there is no fixed factor of production. When schools are improved, and a given amount of spending on education results in more human capital acquired, this causes the expected rate of return on human capital to fall and hence increases the attraction of investing in physical capital, which calls for increased savings and investment. The complementarity of human and physical capital generates an AK production technology where savings and education can sustain growth in the long run.

But how can such a model account for the positive association between equality and growth found in the data? The key lies in diminishing returns to education expenditures. If spending a dollar to further the education of the less educated generates more human capital than the same dollar spent on a person with a better educational background, then improving the efficiency of schools providing basic education - at the expense of those giving elite education - will both enhance equality as well as raising the supply of human capital at the national level. The latter will through a familiar channel - raise the rate of return on physical capital compared with the rate of return on human capital, and this, in turn, generates further saving, investment and growth. The system of education is thus the force that affects both the 
extent of equality and the pace of growth: improvements in the general level of education enhance both equality and growth. Moreover, increased equality will equalize bequests, thereby promoting equality in education and income further still, and higher rates of economic growth.

\section{Cross-country patterns in the data}

The empirical question that we address in this section is this: Does education encourage growth also by enhancing economic and social equality? - provided that equality is also good for growth.

Let us begin by looking at the cross-country pattern of inequality, economic growth and investment. Figure 1a shows a scatterplot of the annual rate of growth of gross national product (GNP) per capita from 1965 to 1998 (World Bank, 2000, Table 1.4) and the inequality of income or consumption as measured by the Gini coefficient (same source, Table 2.8). ${ }^{4}$ The growth rate has been adjusted for initial income: the variable on the vertical axis is that part of economic growth that is not explained by the country's initial stage of development, obtained as a residual from a regression of growth during 1965-1998 on initial GNP per head (i.e., in 1965) as well as natural capital, taken from World Bank (1997). ${ }^{5}$ This adjustment obviates the need to view high-income countries and low-income countries separately. Even so, if rich countries and poor are considered separately, a similar pattern is observed in both groups (not shown). The 75 countries shown in the figure are represented by one observation each. ${ }^{6}$ The regression line through the scatterplot suggests that an increase of about 12 points on the Gini scale from one country to another - corresponding, for example, to

\footnotetext{
${ }^{4}$ Our sample does not include any transition economies because, for them, there is no information available on natural capital, which is one of the key determinants of growth in our framework. See Gylfason and Zoega (2001).

${ }^{5}$ The Gini coefficient measures the extent to which income (or, in some cases, consumption) among individuals or households deviates from a perfectly equal distribution. A Gini coefficient of zero represents perfect equality (all individuals receive the same income) while a Gini coefficient of 100 means perfect inequality (the national income accrues to one individual). While Gini coefficients based on net (i.e., after-tax) incomes are preferable in principle as measures of income inequality, the Gini coefficients published by the World Bank are more often than no based on gross (i.e., before-tax) incomes. Hence, the equalizing effects of taxes and transfer schemes on the distribution of income are not fully reflected in the Gini coefficients used here. The data come from nationally representative household surveys and refer to different years between 1983-85 and 1998-99. See World Bank (2000), Table 2.8.

${ }^{6}$ All countries for which the requisite data are available are included in Figures 1-4, without exception.
} 
the difference in income distribution between India (Gini $=38)$ and Zambia (Gini $=$ 50) - is associated with a decrease in per capita growth by one percentage point per year on average. The relationship is statistically significant (Spearman's rank correlation $r=-0.50){ }^{7}$ A reduction in a country's annual per capita growth rate by one percentage point is a serious matter because the (weighted) average rate of per capita growth in the world economy since 1965 has been about $1 \frac{1}{2}$ percent per year.

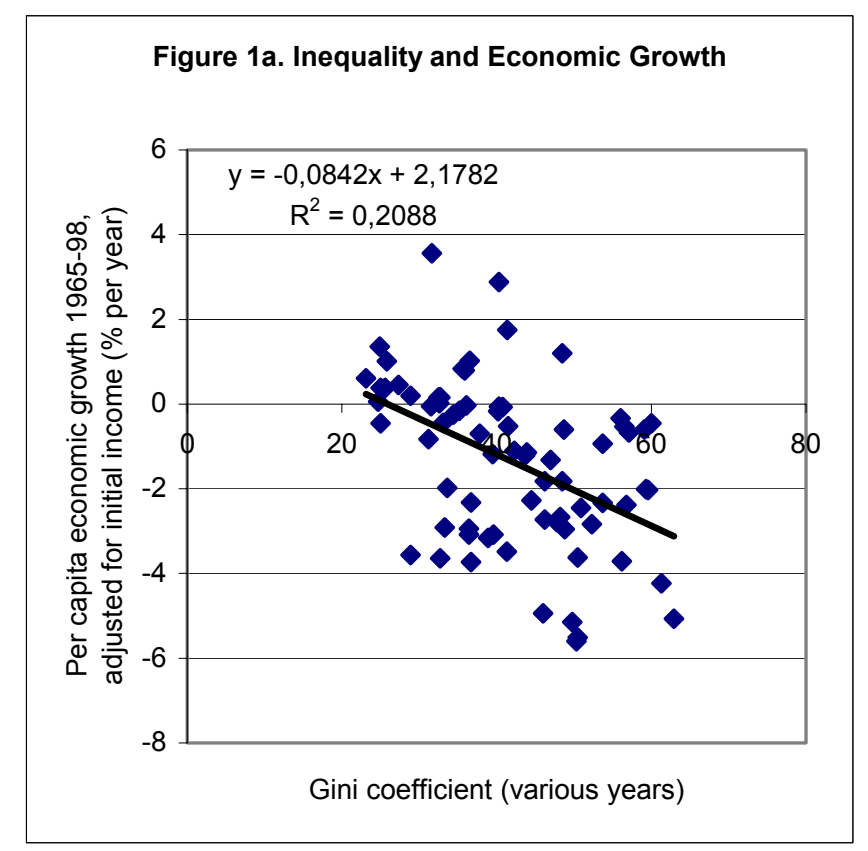

Figure 1b displays a scatterplot of average gross domestic investment from 1965 to 1998 and the Gini coefficient in the same 75 countries as before. Here again we see an inverse correlation, albeit not as strong as in Figure 1a. The regression line through the plot suggests that an increase of about 10 points on the Gini scale from one country to another is associated with a decrease in investment by one percent of gross domestic product (GDP). The relationship is statistically significant $(r=-0.28)$. The outlier in the northeast corner of the scatter is Lesotho $;^{8}$ if we exclude Lesotho from the regression, the rank correlation rises in absolute value to -0.32 and the slope of the regression line increases from -0.10 to -0.15 , in which case an increase in the Gini

\footnotetext{
${ }^{7}$ Elsewhere, we have reported similar cross-country correlations between economic growth and both land inequality $(r=-0.37)$ and gender inequality $(r=-0.32)$. In our data, the distribution of income and land is highly correlated $(r=0.57)$ whereas the distribution income and educational opportunities of the sexes is not $(r=-0.04)$. See Gylfason and Zoega (2003a).

${ }^{8}$ We could be excused for excluding Lesotho because its singularly high investment rate can be explained by a single gigantic project, the Lesotho Highlands Water Project.
} 
coefficient by 10 points from one place to another goes along with a decrease in investment by $1 \frac{1}{2}$ percent of GDP.

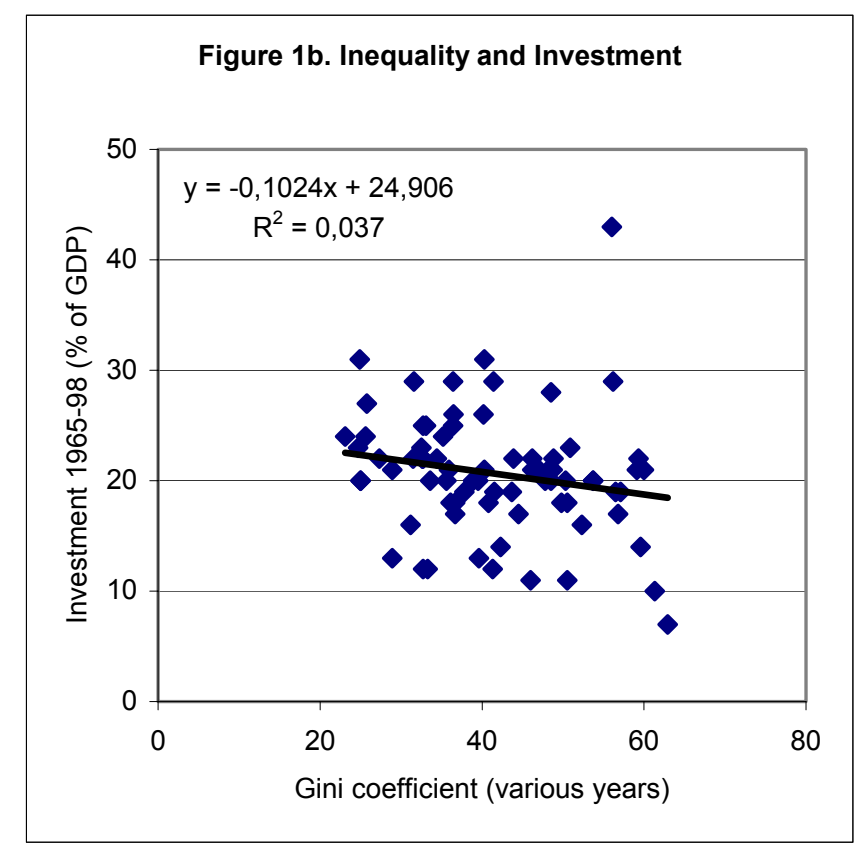

In sum, the data seem compatible with the view that increased inequality in the distribution of income goes hand in hand with less investment and less rapid economic growth across countries. Even so, we are aware that two-dimensional correlations do not allow us to distinguish cause from effect. We intend the correlations presented in this section merely to describe the data in ways that are consistent with the results of the multiple regression analysis in Section 5 where several possible determinants of growth are taken into account side by side.

Let us now consider three different measures of education inputs, outcomes and participation and how they vary with inequality and economic growth. Figure 2 shows scatterplots of public expenditure on education from 1980 to 1997 as reported by UNESCO (see World Bank, 2000, Table 2.9) and (a) inequality and (b) growth as measured above. Public expenditure on education varies a great deal from country to country. In the 1990s, some countries have spent as little as 1 percent of their GNP on education (Haiti, Indonesia, Myanmar, Nigeria and Sudan). Others have spent between 8 percent and 10 percent of their GNP on education, including St. Lucia, Namibia, Botswana and Jordan, in descending order. Public expenditure is admittedly 
an imperfect measure of a nation's commitment to education, not least because some nations spend more on private education than others. ${ }^{9}$
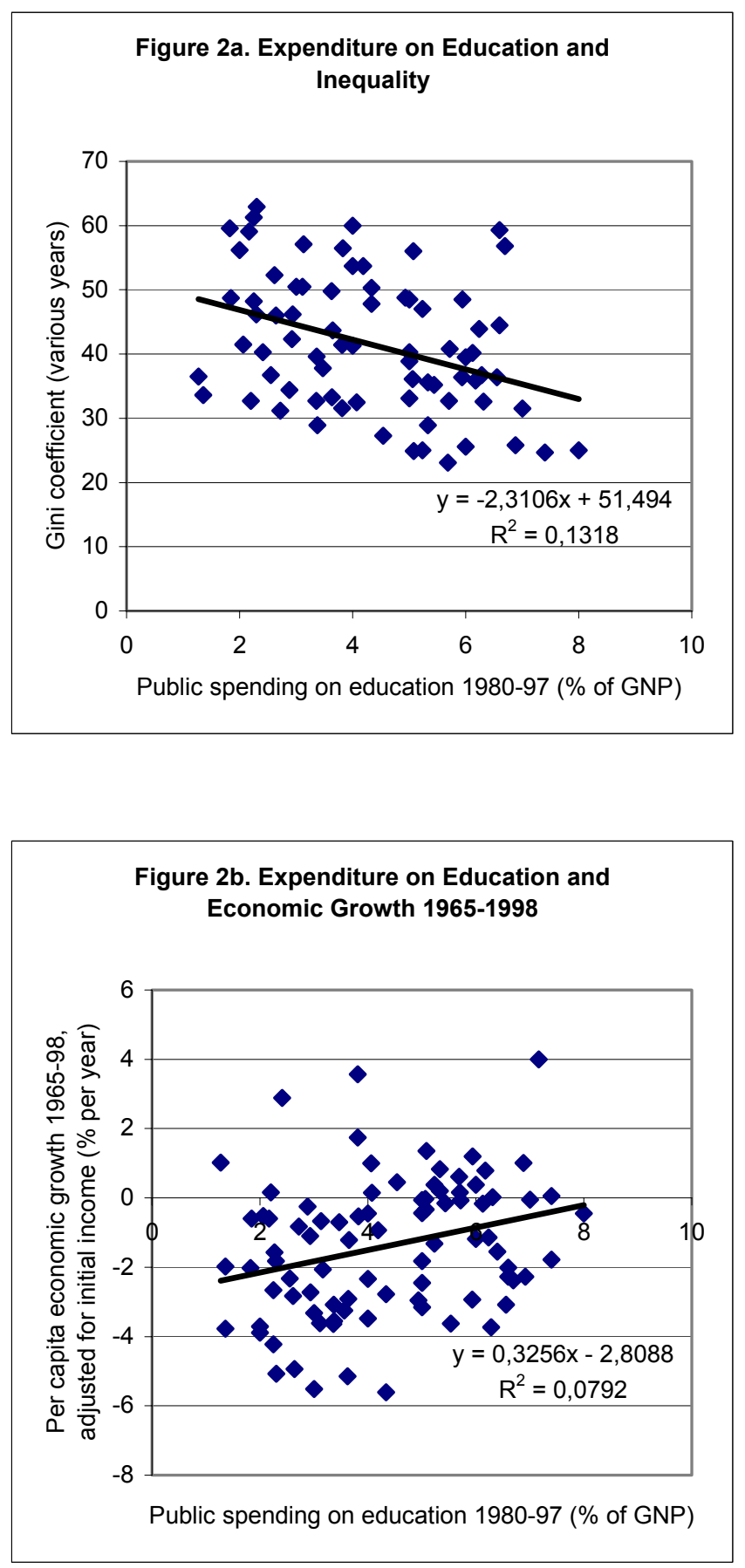

\footnotetext{
${ }^{9}$ Moreover, public expenditure on education may be supply-led and of mediocre quality, and may thus fail to foster efficiency, equality and growth, in contrast to private expenditure on education, which is generally demand-led and thus, perhaps, likely to be of a higher quality. Even so, this yardstick should reflect at least to some extent the government's commitment to education.
} 
The regression line through the 75 observations in Figure 2a suggests that an increase in public expenditure on education by one percent of GNP from one country to the next is associated with a decrease of 2.3 points on the Gini scale. ${ }^{10}$ This pattern can be interpreted either as a sign of the equalizing effects of more public education expenditure or of the education-enhancing effects of less dispersion of education and income, or both. The relationship is statistically significant $(r=-0.36)$. The regression line through the 87 observations in Figure $2 b$ suggests that an increase of about $3 \frac{1}{2}$ percentage points in public expenditure on education relative to GNP from one country to the next is associated with an increase in per capita growth by one percentage point. This relationship is also statistically significant, even if it is not particularly strong $(r=0.29)$. Taken together, the two plots suggest that an increase in education spending by the equivalent of $3 \frac{1}{2}$ percent of GNP goes hand in hand with an eight point decrease in the Gini coefficient and a one percentage point increase in per capita growth on average, thus helping explain the observed cross-country relationship between inequality and growth in Figure 1a. These results are consistent with the theoretical explanation proposed in Section 2 above. A third variable, education expenditures, contributes to both increased equality as well and higher growth.

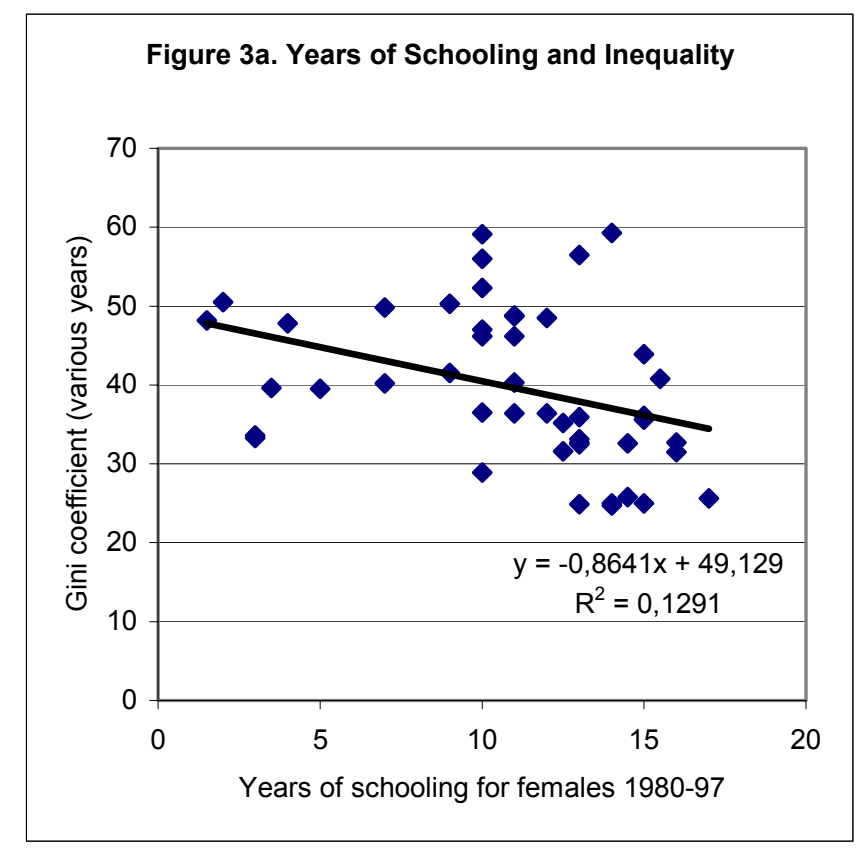

\footnotetext{
${ }^{10}$ Here, unlike in Figures 1a and 1b, Gini coefficients based on the distribution of gross income rather than net income are the most relevant measures of inequality because more and better education can be expected to equalize income before taxes and transfers (see footnote 5).
} 


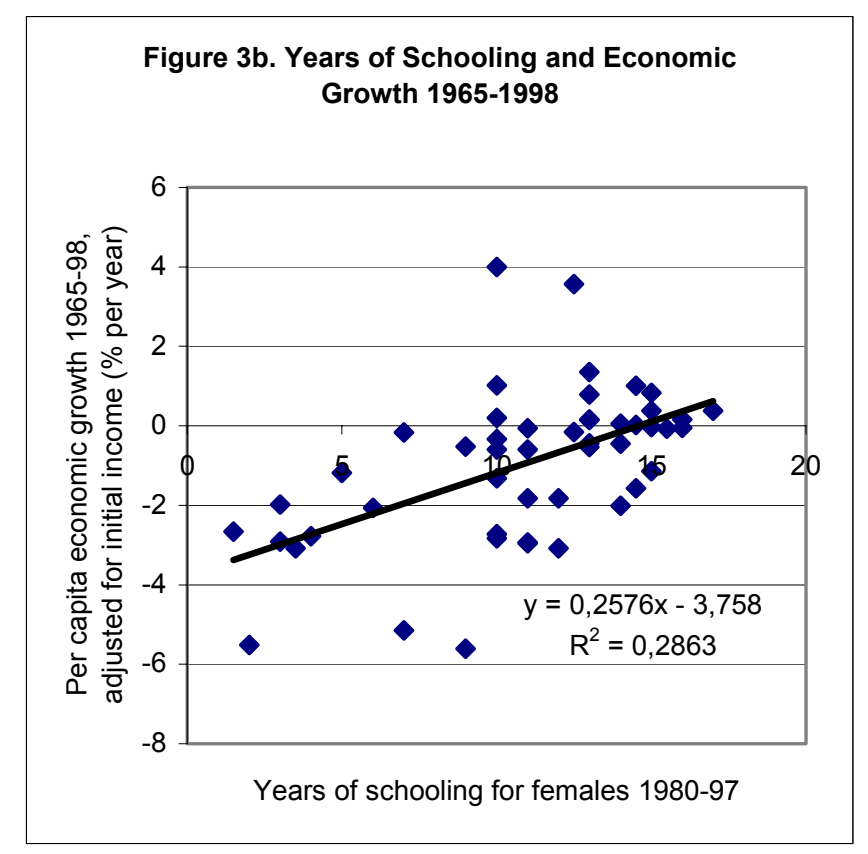

Figure 3 shows scatterplots of the expected number of years of schooling for females from 1980 to 1997 and (a) inequality and (b) growth as before. This indicator of schooling is intended to reflect the total education resources, measured in school years, that a girl will acquire over her lifetime in school or as an indicator of an education system's overall state of development. We stress female education not because using male education would produce weaker results - in fact, the results we get from our sample are virtually the same for both genders (not shown). Rather, we stress the education of girls because the early empirical literature on education and growth did not detect economically and statistically significant effects on growth of female education at any level. In Figure 3a, the regression line through the 46 observations, one per country, suggests that an increase by one year of the schooling that an average girl at the age of school entry can expect to receive is associated with a decrease in the Gini coefficient, i.e., increased equality, by almost one point. The relationship is statistically significant $(r=-0.49)$. Unlike the relationship in Figure 2a, the one in Figure 3a is significantly non-linear (not shown), suggesting that the marginal effect of increased education on equality is rising in the level of enrolment that is, there may be increasing returns to schooling in terms of equality. ${ }^{11}$ The corresponding relationship for males (not shown) is virtually the same as for females. Figure $3 \mathrm{~b}$ shows the cross-country relationship between growth and years of

\footnotetext{
${ }^{11}$ Sen (1999), among others, emphasizes the importance of educating girls in developing countries.
} 
schooling. The regression line through the 49 observations suggests that an extension of schooling by about four years is associated with an increase in annual economic growth by one percentage point. The relationship is significant $(r=0.50)$. Between them, the two charts suggest that an extension of schooling by about four years goes hand in hand with a four point decrease in the Gini coefficient and a one percentage point increase in per capita growth on average, thus again helping explain the inverse relationship between inequality and growth in Figure 1a.
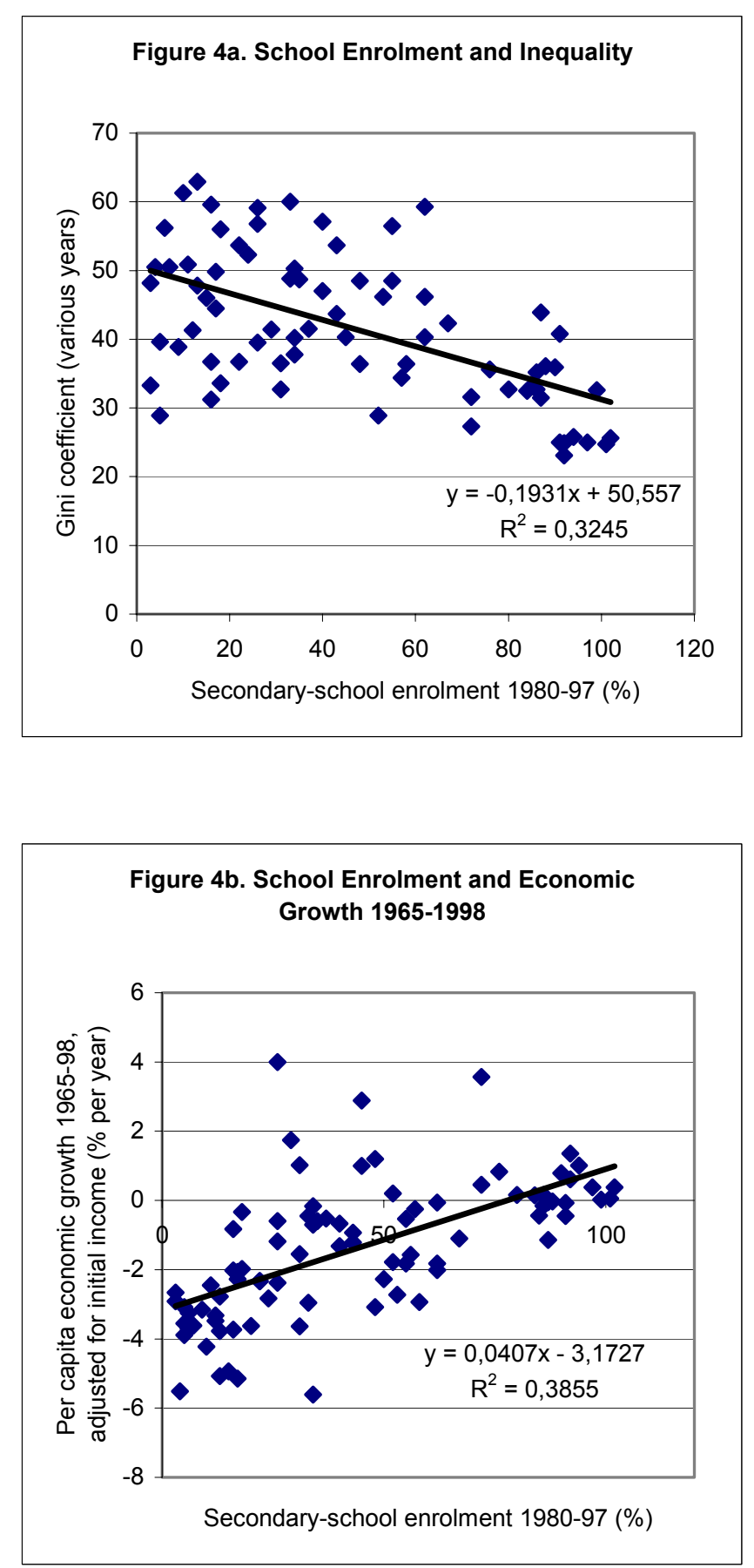
Secondary-school enrolment is probably the most commonly used indicator of education in empirical growth research. Figure 4 shows scatterplots of gross secondary-school enrolment for both genders from 1980 to 1997 and (a) inequality and (b) growth as before. The regression line that passes through the 75 observations in Figure 4a suggests that an increase in the secondary-school enrolment rate by about five percentage points from one place to another goes along with a decrease by one point on the Gini scale. The regression is statistically significant $(r=-0.54)$. Like the relationship in Figure 3a, the one in Figure 4a is significantly non-linear (not shown). At last, Figure $4 \mathrm{~b}$ shows the cross-country relationship between growth and school enrolment. The regression line through the 87 observations suggests that an increase in secondary-school enrolment by $25-30$ percentage points is associated with an increase in annual per capita growth by one percentage point. Unlike the relationships in Figures $2 b$ and $3 b$, the one in Figure $4 b$ is significantly non-linear (not shown), as might be expected from diminishing returns to education. In any case, the relationship is highly significant $(r=0.69)$, more so than in Figures $2 \mathrm{~b}$ and $3 \mathrm{~b}$. Of the three indicators used here, secondary-school enrolment is the one that is most closely correlated with economic growth. Together, the two charts suggest that an increase in secondary-school enrolment by 25-30 percentage points goes hand in hand with a six point decrease in the Gini coefficient and a one percentage point increase in per capita growth on average, thus, once more, illuminating the inverse relationship between inequality and growth in Figure 1.

We now turn to multivariate regression analysis of education, inequality, investment and growth.

\section{Regression analysis}

Table 1 reports seemingly unrelated regression (SUR) estimates of a system of four equations for the 87 countries in our sample for the years 1965-1998.

The first equation shows how economic growth depends on

(i) the logarithm of initial per capita income (i.e., in 1965), defined as income in 1998 divided by an appropriate growth factor,

(ii) the share of natural capital in national wealth (which comprises physical, human and natural capital),

(iii) the share of gross domestic investment in GDP in 1965-1998, 
(iv) the logarithm of the secondary-school enrolment rate (the logarithm in order to capture diminishing returns to education) and

(v) the Gini coefficient.

The second equation shows the relationship between the investment rate and the logarithm of the enrolment rate in accordance with the results derived from the model sketched in Section 2 where we argued that education encourages investment in physical capital. Investment also depends on the natural capital share; the underlying reason is that the more abundant are natural resources in relation to GDP, the smaller the share of physical capital in GDP and the weaker is the incentive to save and invest by the Golden Rule (Gylfason and Zoega, 2001).

The third equation shows how the enrolment rate depends on initial income (because wealthy countries can afford to spend more on education) as well as on natural capital (as in Gylfason, 2001, and Gylfason and Zoega, 2001; the idea behind this formulation is that the natural-resource-intensive sector may use workers with fewer skills than the manufacturing sector).

The fourth and last equation shows the relationship between the Gini coefficient and the enrolment rate that we documented in Section 3. The recursive nature of the system and the conceivable correlation of the error terms in the four equations make SUR an appropriate estimation procedure (Lahiri and Schmidt, 1978). However, the fact that ordinary least squares (OLS) estimates of the system (not shown) are almost the same as the SUR estimates shown in Table 1 indicates that the correlation of errors terms across equations is of minor consequence.

Table 1. Regression Results: Baseline Scenario

\begin{tabular}{|c|c|c|c|c|c|c|c|}
\hline $\begin{array}{l}\text { Dependent } \\
\text { variable }\end{array}$ & $\begin{array}{l}\text { Initial } \\
\text { income }\end{array}$ & $\begin{array}{l}\text { Natural } \\
\text { capital }\end{array}$ & $\begin{array}{l}\text { Investment } \\
\text { rate }\end{array}$ & $\begin{array}{l}\text { Enrolment } \\
\text { rate }\end{array}$ & $\begin{array}{l}\text { Gini } \\
\text { coefficient }\end{array}$ & $R^{2}$ & Countries \\
\hline $\begin{array}{l}\text { Economic } \\
\text { growth }\end{array}$ & $\begin{array}{l}-1.07 \\
(5.62)\end{array}$ & $\begin{array}{l}-0.06 \\
(4.06)\end{array}$ & $\begin{array}{c}0.10 \\
(4.15)\end{array}$ & $\begin{array}{c}0.83 \\
(3.10)\end{array}$ & $\begin{array}{l}-0.03 \\
(2.64)\end{array}$ & $0.6 t$ & 75 \\
\hline $\begin{array}{l}\text { Investment } \\
\text { rate }\end{array}$ & & $\begin{array}{l}-0.13 \\
(2.08)\end{array}$ & & $\begin{array}{c}1.42 \\
(1.92)\end{array}$ & & 0.22 & 87 \\
\hline $\begin{array}{l}\text { Enrolment } \\
\text { rate }\end{array}$ & $\begin{array}{c}20.89 \\
(12.50)\end{array}$ & $\begin{array}{l}-0.70 \\
(4.39)\end{array}$ & & & & 0.72 & 87 \\
\hline $\begin{array}{l}\text { Gini } \\
\text { coefficient }\end{array}$ & & & & $\begin{array}{l}-0.16 \\
(5.10)\end{array}$ & & 0.32 & 75 \\
\hline
\end{tabular}

Note: t-ratios are shown within parentheses. Constant terms, statistically significant throughout, are not reported. 
All the coefficient estimates shown in Table 1 are economically as well as statistically significant with one exception: the effect of enrolment on investment is marginally insignificant at the 0.05 level. The coefficient on initial income in the growth equation suggests that the speed of convergence is about 1 percent per year. The direct effect of natural capital on growth is -0.06 and the indirect effect through investment and education is $-0.13 \cdot 0.10-0.70 \cdot(0.83 / E)-0.70 \cdot(1.42 / E) \cdot 0.10 \approx-0.03$, the latter evaluated at the median value of the enrolment rate, $E=35$. The total effect of natural capital on growth is thus about -0.09 for given initial income.

Of greater interest here, however, are the effects of education and inequality on growth. The first equation in Table 1 shows the direct effect of education on growth to be $0.83 / E \approx 0.02$ at the median value of the enrolment rate; this means that an increase in the enrolment rate by five percentage points from one country to another increases growth by one-tenth of a percentage point. Combining the results reported in the first and fourth row in the table, we see that an increase in the enrolment rate by six points reduces the Gini coefficient by one point and this, in turn, increases growth further by 0.03 percentage points. Further, combining the results reported in the first and second row in the table, we see that an increase in the enrolment rate by 25 points increases investment by one $(\approx 25 \cdot 1.42 / 35)$ percent of GDP and this, in turn, increases growth further by 0.1 percentage points. In sum, the total effect on growth of an increase in the enrolment rate by, say, 30 percentage points - a dire necessity in many developing countries - is about one percentage point, with the indirect effects through increased equality and increased investment accounting for about one-fourth of the total. However, the direct effect of distribution on growth, while significant throughout, is not very large: according to our estimate, it would take an increase of 33 points on the Gini scale from one country to another - corresponding to the difference in income distribution between Norway $(\mathrm{Gini}=26)$ and South Africa $(\mathrm{Gini}=59)$, thus extending from one end of the scale to the other - to produce a decrease in per capita growth by one percentage point per year on average.

Next we want to explore the possibility of interaction between inequality and other determinants of growth, such as initial income, education and investment. The question here is this: Does inequality affect the responsiveness of growth to variations in its main determinants? We begin by replacing the Gini coefficient in the growth equation in Table 1 by the multiple of the Gini coefficient and initial income. We see 
in Table 2 that the results remain virtually the same as in Table 1 except for the changes in the coefficients of initial income and the new interaction variable. The speed of conditional convergence now depends on inequality: the composite coefficient of initial income is now $-0.92-0,004 \cdot G i n i \approx-1.08$ for given education, given the median value of the Gini coefficient in the sample (Gini=40.3). Taking the effect of initial income on education into account, we see that the speed of absolute convergence is considerably lower, or $-0.92-0,004 \cdot 40.3+(0.85 / 35) \cdot 20.90 \approx-0.57$. The results in Table 2 also suggest that changes in the distribution of income have stronger effects on growth in rich countries than in poor ones. Moreover, our crosscountry data support the notion of a Kuznets curve (see Gylfason and Zoega, 2003a): Inequality tends to increase with income at low levels of income and to decrease with income at higher levels of income.

\section{Table 2. Further Results: Gini Interacts with Initial Income}

\begin{tabular}{|c|c|c|c|c|c|c|c|}
\hline $\begin{array}{l}\text { Dependent } \\
\text { variable }\end{array}$ & $\begin{array}{l}\text { Initial } \\
\text { income }\end{array}$ & $\begin{array}{l}\text { Natural } \\
\text { capital }\end{array}$ & $\begin{array}{l}\text { Investment } \\
\text { rate }\end{array}$ & $\begin{array}{l}\text { Enrolment } \\
\text { rate }\end{array}$ & $\begin{array}{l}\text { Gini times } \\
\text { initial } \\
\text { income }\end{array}$ & $R^{2}$ & Countries \\
\hline $\begin{array}{l}\text { Economic } \\
\text { growth }\end{array}$ & $\begin{array}{l}-0.92 \\
(4.62)\end{array}$ & $\begin{array}{l}-0.06 \\
(4.15)\end{array}$ & $\begin{array}{c}0.10 \\
(4.05)\end{array}$ & $\begin{array}{c}0.85 \\
(3.17)\end{array}$ & $\begin{array}{l}-0.004 \\
(2.68)\end{array}$ & $0.6 t$ & 75 \\
\hline $\begin{array}{l}\text { Investment } \\
\text { rate }\end{array}$ & & $\begin{array}{l}-0.13 \\
(2.08)\end{array}$ & & $\begin{array}{c}1.42 \\
(1.92)\end{array}$ & & 0.22 & 87 \\
\hline $\begin{array}{l}\text { Enrolment } \\
\text { rate }\end{array}$ & $\begin{array}{c}20.90 \\
(12.50)\end{array}$ & $\begin{array}{l}-0.70 \\
(4.39)\end{array}$ & & & & 0.72 & 87 \\
\hline $\begin{array}{l}\text { Gini } \\
\text { coefficient }\end{array}$ & & & & $\begin{array}{l}-0.16 \\
(5.10)\end{array}$ & & 0.32 & 75 \\
\hline
\end{tabular}

Note: t-ratios are shown within parentheses. Constant terms, statistically significant throughout, are not reported.

How about education? In Table 3 we have replaced the Gini coefficient from Table 1 with the multiple of the Gini coefficient and the secondary-school enrolment rate. Again, the results are virtually the same as in Table 1 except for the changes in the coefficients of the enrolment rate and the new interaction variable. The direct effect of education on growth is now $1.25 / E-0.01 \cdot \mathrm{Gini} / \mathrm{E} \approx 0.02$, evaluated at the median values of $E$ and Gini. This suggests that increased inequality in the distribution of income reduces the contribution of increased education to growth and also that the more educated the population, the stronger the adverse effect of increased inequality on economic growth. 
Table 3. Further Results: Gini Interacts with Education

\begin{tabular}{|c|c|c|c|c|c|c|c|}
\hline $\begin{array}{l}\text { Dependent } \\
\text { variable }\end{array}$ & $\begin{array}{l}\text { Initial } \\
\text { income }\end{array}$ & $\begin{array}{l}\text { Natural } \\
\text { capital }\end{array}$ & $\begin{array}{l}\text { Investment } \\
\text { rate }\end{array}$ & $\begin{array}{l}\text { Enrolment } \\
\text { rate }\end{array}$ & $\begin{array}{l}\text { Gini times } \\
\text { enrolment } \\
\text { rate }\end{array}$ & $R^{2}$ & Countries \\
\hline $\begin{array}{l}\text { Economic } \\
\text { growth }\end{array}$ & $\begin{array}{l}-1.11 \\
(5.88)\end{array}$ & $\begin{array}{l}-0.06 \\
(4.30)\end{array}$ & $\begin{array}{c}0.10 \\
(3.97)\end{array}$ & $\begin{array}{c}1.25 \\
(4.50)\end{array}$ & $\begin{array}{l}-0.010 \\
(2.82)\end{array}$ & $0.6 i$ & 75 \\
\hline $\begin{array}{l}\text { Investment } \\
\text { rate }\end{array}$ & & $\begin{array}{l}-0.13 \\
(2.08)\end{array}$ & & $\begin{array}{c}1.42 \\
(1.92)\end{array}$ & & 0.22 & 87 \\
\hline $\begin{array}{l}\text { Enrolment } \\
\text { rate }\end{array}$ & $\begin{array}{c}20.90 \\
(12.50)\end{array}$ & $\begin{array}{l}-0.70 \\
(4.39)\end{array}$ & & & & 0.72 & 87 \\
\hline $\begin{array}{l}\text { Gini } \\
\text { coefficient }\end{array}$ & & & & $\begin{array}{l}-0.16 \\
(5.10)\end{array}$ & & 0.32 & 75 \\
\hline
\end{tabular}

Note: t-ratios are shown within parentheses. Constant terms, statistically significant throughout, are not reported.

A similar pattern emerges when we replace the multiple of the Gini coefficient and the secondary-school enrolment rate in Table 3 by the multiple of Gini and the investment rate (not shown). The effect of investment on growth varies inversely with the Gini coefficient, which implies that large inequalities tend to spoil the efficiency of investments in physical as well as human capital. Also, high investment, like high school-enrolment, exacerbates the effect of inequality on growth.

When we replace the multiple of the Gini coefficient and the secondary-school enrolment rate in Table 3 by the multiple of Gini and our natural capital variable, both the natural capital variable and the new interaction variable turn insignificant (not shown). This suggests that inequality does not affect growth through natural resources. On the other hand, we have elsewhere reported evidence of interaction between inequality and natural capital in our growth equation suggesting that natural resources matter for growth through the distribution of income, among other channels (Gylfason and Zoega, 2003a).

We also examined the possibility of interaction between initial income and education. Our results remained essentially unchanged except now the growth effect of increased secondary-school enrolment varied directly and significantly with initial income while the speed of convergence varied inversely with enrolment (not shown). Our estimates of other linkages, reported in Tables 1-3, were not affected by this change in specification.

Our last experiment involves regional dummy variables. We want to make sure that the relationship between inequality and growth that we have documented here 
survives the introduction of dummies for Africa, Central and South America, and last but not least Asia. When we introduce a dummy for Africa into our model, either on its own or interacting with the Gini coefficient in the growth equation, the only material effect of this extension on our results is that our estimates of the effects of school enrolment on growth and of natural capital on investment become insignificant in a statistical sense. The results in Table 4 suggest that African countries have grown less rapidly than the rest of the world, invested less and sent fewer youngsters to secondary school, but only the growth effect is statistically significant. There is, in particular, no evidence that the Gini coefficient has been different in Africa than elsewhere.

Table 4. Further Results: Dummy for Africa

\begin{tabular}{|lccccccc|}
\hline $\begin{array}{l}\text { Dependent } \\
\text { variable }\end{array}$ & $\begin{array}{l}\text { Initial } \\
\text { income }\end{array}$ & $\begin{array}{l}\text { Natural } \\
\text { capital }\end{array}$ & $\begin{array}{l}\text { Investment } \\
\text { rate }\end{array}$ & $\begin{array}{l}\text { Enrolment } \\
\text { rate }\end{array}$ & $\begin{array}{l}\text { Gini } \\
\text { coefficient }\end{array}$ & $\boldsymbol{R}^{2}$ & $\begin{array}{l}\text { African } \\
\text { dummy }\end{array}$ \\
\hline $\begin{array}{l}\text { Economic } \\
\text { growth }\end{array}$ & -1.02 & -0.05 & 0.10 & 0.46 & -0.03 & $0.6 \varepsilon$ & -1.08 \\
Investment & $(5.53)$ & $(3.65)$ & $(4.18)$ & $(1.58)$ & $(2.84)$ & & $(2.70)$ \\
rate & & -0.12 & & 0.36 & & 0.22 & -0.62 \\
$\begin{array}{l}\text { Enrolment } \\
\text { rate }\end{array}$ & 19.71 & -0.63 & & $(1.54)$ & & & $(0.40)$ \\
Gini & $(10.58)$ & $(3.68)$ & & & & 0.73 & -5.84 \\
coefficient & & & & -0.17 & & 0.32 & -0.30 \\
\hline
\end{tabular}

Note: t-ratios are shown within parentheses. Constant terms, statistically significant throughout, are not reported. The number of countries is the same as in Tables 1-3.

When we repeat the experiment for Central and South America, we get the results shown in Table 5. Again, we find that the Central and South American countries have grown slightly less rapidly than the rest of the world, invested less, sent far fewer youngsters to secondary school and have had a vastly more unequal distribution of income - equivalent to 10 extra points in the Gini scale! However, only the last two effects are statistically significant. In other respects, the results in Table 5 are similar as in Table 1 except the direct effect of the Gini coefficient on growth becomes marginally insignificant.

At last, we do the same for Asia. In Table 6, once again, our results do by and large remain unchanged. Now the regional dummy is significant in all four equations of our system. The Asian economies have grown faster, invested more, sent more of their youths to secondary school, and have tolerated less inequality in the distribution 
of income than the world at large. Thus, our results on inequality and growth around the world cannot be traced to Africa or Central and South America, nor, perhaps more surprisingly, can they be attributed to Asia's remarkable combination of rapid economic growth and greater equality in the distribution of income than has been achieved elsewhere in the developing world.

Table 5. Further Results: Dummy for Central and South America

\begin{tabular}{|lccccccc|}
\hline $\begin{array}{l}\text { Dependent } \\
\text { variable }\end{array}$ & $\begin{array}{l}\text { Initial } \\
\text { income }\end{array}$ & $\begin{array}{l}\text { Natural } \\
\text { capital }\end{array}$ & $\begin{array}{l}\text { Investment } \\
\text { rate }\end{array}$ & $\begin{array}{l}\text { Enrolment } \\
\text { rate }\end{array}$ & $\begin{array}{l}\text { Gini } \\
\text { coefficient }\end{array}$ & $\boldsymbol{R}^{2}$ & $\begin{array}{l}\text { Central \& } \\
\text { South } \\
\text { American } \\
\text { dummy }\end{array}$ \\
\hline $\begin{array}{l}\text { Economic } \\
\text { growth }\end{array}$ & -1.05 & -0.06 & 0.10 & 0.85 & -0.03 & 0.6 & -0.25 \\
$\begin{array}{l}\text { Investment } \\
\text { rate }\end{array}$ & $(5.56)$ & $(4.18)$ & $(3.94)$ & $(3.14)$ & $(1.78)$ & & $(0.71)$ \\
$\begin{array}{l}\text { Enrolment } \\
\text { rate }\end{array}$ & -0.14 & & 1.54 & & 0.26 & -2.43 \\
$\begin{array}{l}\text { Gini } \\
\text { coefficient }\end{array}$ & $(1.34)$ & -0.79 & & $(2.11)$ & & & $(1.93)$ \\
\hline
\end{tabular}

Note: t-ratios are shown within parentheses. Constant terms, statistically significant throughout, are not reported. The number of countries is the same as in Tables 1-3.

Table 6. Further Results: Dummy for Asia

\begin{tabular}{|lccccccc|}
\hline $\begin{array}{l}\text { Dependent } \\
\text { variable }\end{array}$ & $\begin{array}{l}\text { Initial } \\
\text { income }\end{array}$ & $\begin{array}{l}\text { Natural } \\
\text { capital }\end{array}$ & $\begin{array}{l}\text { Investment } \\
\text { rate }\end{array}$ & $\begin{array}{l}\text { Enrolment } \\
\text { rate }\end{array}$ & $\begin{array}{l}\text { Gini } \\
\text { coefficient }\end{array}$ & $\boldsymbol{R}^{2}$ & $\begin{array}{l}\text { Asian } \\
\text { dummy }\end{array}$ \\
\hline $\begin{array}{l}\text { Economic } \\
\text { growth }\end{array}$ & -0.81 & -0.06 & 0.10 & 0.62 & -0.03 & 0.6 & 0.82 \\
Investment & $(3.61)$ & $(4.22)$ & $(3.89)$ & $(2.24)$ & $(2.31)$ & & $(2.07)$ \\
rate & & -0.11 & & 1.60 & & 0.28 & 3.71 \\
Enrolment & 22.24 & -0.63 & & $(2.22)$ & & & $(2.55)$ \\
rate & $(12.96)$ & $(3.99)$ & & & & 0.75 & 15.33 \\
Gini & & & & -0.17 & & 0.36 & -5.44 \\
coefficient & & & & $(5.57)$ & & & $(2.14)$ \\
\hline
\end{tabular}

Note: t-ratios are shown within parentheses. Constant terms, statistically significant throughout, are not reported. The number of countries is the same as in Tables 1-3. 


\section{Conclusion}

We have described intuitively how endogenous growth can arise in an overlapping generations model of education and growth and used it to argue that more and better education financed by public expenditure can encourage economic growth and reduce inequality in the distribution of income as well. We looked at data for 87 countries around the world and showed that, across countries, (i) economic growth varies inversely with inequality; (ii) three different measures of education intended to reflect education inputs, outcomes and participation are all inversely related to inequality; and (iii) economic growth varies directly with all three measures of education. We then used seemingly unrelated regression analysis to demonstrate that both education and inequality have a significant, independent impact on growth, even if education and inequality are closely correlated. Our conclusion is that education seems likely to encourage economic growth not only by increasing and improving human capital but also physical capital and social capital - that is, by reducing inequality. If so, the inverse association between inequality on economic growth since the mid-1960s that has been reported in the literature may in part reflect the favourable effects of more and better education on both economic growth and social equality. 


\section{References}

Aghion, Philippe (1998), with Eve Caroli and Cecilia García-Peñalosa, "Inequality and Economic Growth," Part I in Philippe Aghion and Jeffrey G. Williamson, Growth, Inequality and Globalization: Theory, History and Policy, Cambridge University Press, Cambridge, England.

Aghion, Philippe, Eve Caroli and Cecilia García-Peñalosa (1999), "Inequality and Economic Growth: The Perspective of the New Growth Theories," Journal of Economic Literature 37, December, 1615-1660.

Alesina, Alberto, and Dani Rodrik (1994), "Distributive Politics and Economic Growth," Quarterly Journal of Economics 109, May, 165-190.

Barro, Robert J. (2000), “Inequality and Growth in a Panel of Countries,” Journal of Economic Growth 5, March, 5-32.

Bénabou, Roland (1996), "Inequality and Growth," NBER Macroeconomics Annual. Benhabib, Jess, and Aldo Rustichini (1996), “Social Conflict and Growth,” Journal of Economic Growth 1, March, 124-142.

Galor, Oded, and Joseph Zeira (1993), "Income Distribution and Macroeconomics," Review of Economic Studies 60, January, 35-52.

Gylfason, Thorvaldur (2001), "Natural Resources, Education, and Economic Development," European Economic Review 45, May, 847-859.

Gylfason, Thorvaldur, and Gylfi Zoega (2001), "Natural Resources and Economic Growth: The Role of Investment," CEPR Discussion Paper No. 2743, March. Gylfason, Thorvaldur, and Gylfi Zoega (2003a), "Inequality and Economic Growth: Do Natural Resources Matter?”, Chapter 9 in Theo Eicher and Stephen Turnovsky (eds.), Growth and Inequality: Theory and Policy Implications, MIT Press (forthcoming).

Gylfason, Thorvaldur, and Gylfi Zoega (2003b), "Inequality and Economic Growth:

Does Education Matter?”, CEPR Discussion Paper (forthcoming).

Kaldor, Nicholas (1956), “Alternative Theories of Distribution,” Review of Economic Studies 23, 83-100.

Lahiri, Kajal, and Peter Schmidt (1978), “On the Estimation of Triangular Structural Systems," Econometrica 46, 1217-1221.

Perotti, Robert (1996), “Growth, Income Distribution, and Democracy: What the Data Say," Journal of Economic Growth 5, June, 149-187. 
Persson, Torsten, and Guido Tabellini (1994), "Is Inequality Harmful for Growth?," American Economic Review 84, June, 600-621.

Sen, Amartya (1999), Development as Freedom, Oxford University Press, Oxford.

Todaro, Michael P. (1997), Economic Development, Longman, London.

World Bank (1997), "Expanding the Measure of Wealth: Indicators of Environmentally Sustainable Development," Environmentally Sustainable Development Studies and Monographs Series No. 17, World Bank, Washington, D.C.

World Bank (2000), World Development Indicators 2000, World Bank, Washington, D.C. 


\title{
CESifo Working Paper Series
}

\author{
(for full list see www.cesifo.de)
}

812 Stéphanie Stolz, Banking Supervision in Integrated Financial Markets: Implications for the EU, December 2002

813 Christian Keuschnigg, Taxation of a Venture Capitalist with a Portfolio of Firms, December 2002

814 Inés Macho-Stadler and David Pérez-Castrillo, Settlement in Tax Evasion Prosecution, December 2002

815 Rainer Niemann and Dirk Simons, Costs, Benefits, and Tax-induced Distortions of Stock Option Plans, December 2002

816 Jan-Egbert Sturm and Barry Williams, Deregulation, Entry of Foreign Banks and Bank Efficiency in Australia, December 2002

817 V. Anton Muscatelli, Patrizio Tirelli, and Carmine Trecroci, Monetary and Fiscal Policy Interactions over the Cycle: Some Empirical Evidence, December 2002

818 Claude Hillinger, A General Theory of Price and Quantity Aggregation and Welfare Measurement, December 2002

819 Erkki Koskela and Ronnie Schöb, Optimal Capital Taxation in Economies with Unionised and Competitive Labour Markets, December 2002

820 Sheilagh Ogilvie, Guilds, Efficiency, and Social Capital: Evidence from German ProtoIndustry, December 2002

821 Hans Gersbach and Verena Liessem, Financing Democracy, December 2002

822 Costas Hadjiyiannis, Panos Hatzipanayotou, and Michael S. Michael, Optimal Tax Policies with Private-Public Clean-Up, Cross-Border Pollution and Capital Mobility, December 2002

823 François Ortalo-Magné and Sven Rady, Homeownership: Low Household Mobility, Volatile Housing Prices, High Income Dispersion, December 2002

824 Syed M. Ahsan and Panagiotis Tsigaris, Measuring the Social Discount Rate under Uncertainty: A Methodology and Application, December 2002

825 Kai A. Konrad, Altruism and Envy in Contests: An Evolutionarily Stable Symbiosis, December 2002 
826 Robert S. Chirinko and Huntley Schaller, A Revealed Preference Approach to Understanding Corporate Governance Problems: Evidence from Canada, December 2002

827 Geir B. Asheim, Green National Accounting for Welfare and Sustainability: A Taxonomy of Assumptions and Results, December 2002

828 Andrea Gebauer, Chang Woon Nam, and Rüdiger Parsche, Lessons of the 1999 Abolition of Intra-EU Duty Free Sales for Eastern European EU Candidates, December 2002

829 Giacomo Corneo, Work and Television, December 2002

830 Vivek H. Dehejia and Yiagadeesen Samy, Trade and Labour Standards - Theory, New Empirical Evidence, and Policy Implications, December 2002

831 Geir B. Asheim and Wolfgang Buchholz, A General Approach to Welfare Measurement through National Income Accounting, December 2002

832 Aaron Tornell and Frank Westermann, The Credit Channel in Middle Income Countries, January 2003

833 Gebhard Flaig, Time Series Properties of the German Monthly Production Index, January 2003

834 Campbell Leith and Jim Malley, Estimated Open Economy New Keynesian Phillips Curves for the G7, January 2003

835 Burkhard Heer and Bernd Süssmuth, Inflation and Wealth Distribution, January 2003

836 Erkki Koskela and Leopold von Thadden, Optimal Factor Taxation under Wage Bargaining - A Dynamic Perspective, January 2003

837 Carola Grün and Stephan Klasen, Growth, Income Distribution, and Well-Being: Comparisons across Space and Time, January 2003

838 Robert S. Chirinko and Ulf von Kalckreuth, On the German Monetary Transmission Mechanism: Interest Rate and Credit Channels for Investment Spending, January 2003

839 Sascha O. Becker, Andrea Ichino, and Giovanni Peri, How Large is the "Brain Drain" from Italy?", January 2003

840 Albert Berry and John Serieux, All About the Giants: Probing the Influences on Growth and Income Inequality at the End of the $20^{\text {th }}$ Century, January 2003

841 Robert Fenge and Martin Werding, Ageing and the Tax Implied in Public Pension Schemes: Simulations for Selected OECD Countries, January 2003

842 Robert Fenge and Martin Werding, Ageing and Fiscal Imbalances Across Generations: Concepts of Measurement, January 2003 
843 Giovanni Andrea Cornia, The Impact of Liberalisation and Globalisation on Income Inequality in Developing and Transitional Economies, January 2003

844 Peter Fredriksson and Per Johansson, Program Evaluation and Random Program Starts, January 2003

845 Bernd Hayo and Matthias Wrede, Fiscal Equalisation: Principles and an Application to the European Union, January 2003

846 Syed M. Ahsan and Jaideep Oberoi, Inequality, Well-being and Institutions in Latin America and the Caribbean, January 2003

847 Chang Woon Nam and Doina Maria Radulescu, The Role of Tax Depreciation for Investment Decisions: A Comparison of European Transition Countries, January 2003

848 V. Bhaskar and Steinar Holden, Wage Differentiation via Subsidised General Training, January 2003

849 Paloma Lopez-Garcia, Labour Market Performance and Start-up Costs: OECD Evidence, January 2003

850 Christian Keuschnigg and Soren Bo Nielsen, Public Policy for Start-up Entrepreneurship with Venture Capital and Bank Finance, January 2003

851 Yin-Wong Cheung, Menzie D. Chinn, and Eiji Fujii, China, Hong Kong, and Taiwan: A Quantitative Assessment of Real and Financial Integration, January 2003

852 Gregory D. Hess, The Economic Welfare Cost of Conflict: An Empirical Assessment, February 2003

853 Douglas J. Cumming and Jeffrey G. MacIntosh, Comparative Venture Capital Governance. Private versus Labour Sponsored Venture Capital Funds, February 2003

854 Eckhard Janeba and John Douglas Wilson, Decentralization and International Tax Competition, February 2003

855 Tapio Palokangas, Capital Accumulation and Employment Cycles in a Model of Creative Destruction, February 2003

856 Brendan Walsh, When Unemployment Disappears: Ireland in the 1990s, February 2003

857 Luis H. R. Alvarez and Erkki Koskela, A General Approach to the Stochastic Rotation Problem with Amenity Valuation, February 2003

858 Christian Schultz, Strategic Campaigns and Redistributive Politics, February 2003

859 Ernst Fehr and Joseph Henrich, Is Strong Reciprocity a Maladaptation? On the Evolutionary Foundations of Human Altruism, February 2003

860 Haizhou Huang, Dalia Marin, and Chenggang Xu, Financial Crisis, Economic Recovery and Banking Development in Former Soviet Union Economies, February 2003 
861 Pedro Cardoso and Bernard M.S. van Praag, How Sustainable Are Old-age Pensions in a Shrinking Population with Endogenous Labour Supply?, February 2003

862 Volker Meier, Efficient Transfer of Aging Provisions in Private Health Insurance, February 2003

863 Edward Castronova, Theory of the Avatar, February 2003

864 Robert S. Chirinko, Hans van Ees, Harry Garretsen, and Elmer Sterken, Investor Protections and Concentrated Ownership: Assessing Corporate Control Mechanisms in the Netherlands, February 2003

865 Bernard M.S. van Praag and Pedro Cardoso, The Mix Between Pay-as-you-go and Funded Pensions and what Demography has to do with it, February 2003

866 Ernst Fehr, Urs Fischbacher, Bernhard von Rosenbladt, Jürgen Schupp, and Gert G. Wagner, A Nation-Wide Laboratory. Examining Trust and Trustworthiness by Integrating Behavioral Experiments into Representative Survey, February 2003

867 Frank Heinemann, The Inflationary Impact of Wage Indexation, February 2003

868 Eytan Sheshinski, Bounded Rationality and Socially Optimal Limits on Choice in a Self-Selection Model, February 2003

869 M. Hashem Pesaran, Estimation and Inference in Large Heterogenous Panels with Cross Section Dependence, February 2003

870 Luis H. R. Alvarez and Erkki Koskela, On the Tree-Cutting Problem under Interest Rate and Forest Value Uncertainty, February 2003

871 Norbert Berthold and Rainer Fehn, Unemployment in Germany: Reasons and Remedies, February 2003

872 Clemens Fuest, Bernd Huber, and Philipp Tilleßen, Tax Policy and Entrepreneurship in the Presence of Asymmetric Information in Capital Markets, February 2003

873 Eytan Sheshinski, Optimum and Risk-Class Pricing of Annuities, February 2003

874 Willi Leibfritz, Paul O'Brien and Jean-Christophe Dumont, Effects of Immigration on Labour Markets and Government Budgets - An Overview, February 2003

875 M. Hashem Pesaran and Allan Timmermann, How Costly is it to Ignore Breaks when Forecasting the Direction of a Time Series?, February 2003

876 Thorvaldur Gylfason and Gylfi Zoega, Education, Social Equality and Economic Growth: A View of the Landscape, February 2003 